\title{
A NEW SECO-LIMONOID FROM THE INFLORESCENCES OF Dictyoloma vandellianum
}

\author{
Laiane Caline Oliveira Pereira ${ }^{a}$, Lucas Silva Abreu, ${ }^{a}$, Mayra Bitencourt Silveira $^{\mathrm{b}}$, Yuri Mangueira do Nascimento ${ }^{\mathrm{a}}$, \\ Thalisson Amorim de Souza ${ }^{a}$, Mireille Le Hyaric ${ }^{c}$, Thaís Mangeon Honorato Lisboa ${ }^{a}$, Marianna Vieira Sobrala ${ }^{a}$ Eudes da \\ Silva Velozo ${ }^{\mathrm{b}}$, Josean Fechine Tavares ${ }^{\mathrm{a}, *, \text {,i) }}$ e Marcelo Sobral da Silva ${ }^{\mathrm{a}}$

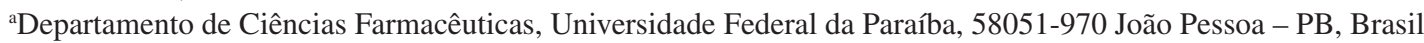

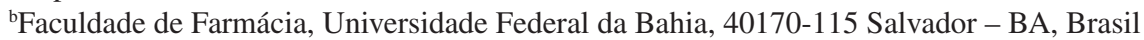 \\ 'Departamento de Química, Instituto de Ciências Exatas, Universidade Federal de Juiz de Fora, 36036-900 Juiz de Fora - MG, Brasil
}

Recebido em 01/11/2019; aceito em 17/02/2020; publicado na web em 13/04/2020

\begin{abstract}
Phytochemical investigation of the inflorescences of Dictyoloma vandellianum A. Juss. (Rutaceae) has led to the isolation of a new A-seco-limonoid, named dictyolomol (1), along with a known quinolone alkaloid, casimiroine (2), previously isolated from the same species. The structures were established by spectroscopic analysis such as one- and two-dimensional NMR, IR, high-resolution mass spectrometry and chemical transformations. The isolated compounds (1 and $\mathbf{2})$ and $O$-acetyl derivative (1a) were evaluated for their cytotoxicity against MCF-7 and HeLa cancer cell lines. The results indicated that 1, 1a and $\mathbf{2}$ showed no significant cytotoxicity.
\end{abstract}

Keywords: A-seco-limonoid; alkaloid; Dictyoloma vandellianum; Rutaceae; cytotoxicity.

\section{INTRODUCTION}

The genus Dictyoloma contains two species, Dictyoloma peruvianum, which occurs in Peru and Bolivia, and Dictyoloma vandellianum A. JUSS., in Brazil. ${ }^{1}$ Previous phytochemical investigations of $D$. vandellianum have demonstrated the presence of limonoids, quinolone alkaloids, and pyranochromones..$^{2-5}$ Although hundreds of limonoids have been isolated from various plants, their occurrence in the plant kingdom is limited to plants belonging to Rutales, especially Meliaceae and Rutaceae. ${ }^{6,7}$ Therefore, these compounds have been important for systematic classification of the genus in the Rutaceae family., ${ }^{3,9}$ Recently, it was evaluated the antinociceptive activity of hydrolysable tannins isolated from the methanol extract from leaves, anti-inflammatory activity and cytotoxic of pyranochromones from dichloromethane extract from root barks of $D$. vandellianum. ${ }^{2,10}$

Natural products continue to be a major source of new drugs, and they may be used as prototypes for design of lead molecules. ${ }^{11,12}$ From 1940 to 2014, 175 small molecules were approved for cancer treatment, nearly half were natural products or directly derived from them. ${ }^{13}$ In this context, literature reports have been described different classes of secondary metabolites with antitumor activity, such as limonoids ${ }^{14,15}$ and alkaloids. ${ }^{16,17}$ Although, several limonoids have been found to exhibited a range of biological activities like insecticidal, insect antifeedant and growth regulating activity on insects. ${ }^{6,18}$

Considering the chemical and pharmacological potential of the $D$. vandellianum, an investigation of chloroform extract from inflorescences was performed leading to the isolation of a new A-secolimonoid, dictyolomol (1). The structure of this compound and the corresponding acetyl derivative 1a were elucidated by $1 \mathrm{D}$ and $2 \mathrm{D}$ NMR, HRESIMS and IR. In addition, a known quinolone alkaloid previously described was identified as casimiroine (2), isolated from the same species. ${ }^{9}$ The compounds obtained were screened for their cytotoxic activities.

\footnotetext{
*e-mail: josean@ltf.ufpb.br
}

\section{RESULTS AND DISCUSSION}

The inflorescences of $D$. vandellianum were used to obtain a chloroform extract, which was fractionated by silica gel column chromatography and further purified to afford a new limonoid (1) and casimiroine (2) (Figure 1), previously found on this species. ${ }^{9}$
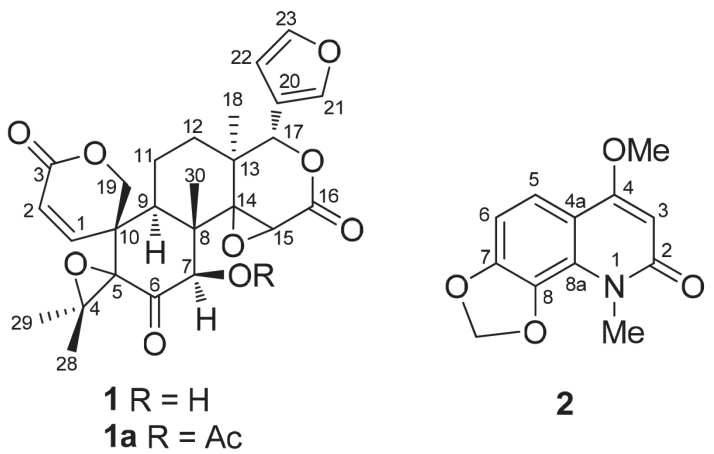

Figure 1. Dictyolomol (1), O-acetyl derivative (1a) and casimiroine (2) isolated from the D. vandellianum

Compound $\mathbf{1}$ was isolated as a white powder with molecular formula of $\mathrm{C}_{26} \mathrm{H}_{28} \mathrm{O}_{9}$, as deduced from the HRESIMS analysis $\left(m / z, 485.1807[\mathrm{M}+\mathrm{H}]^{+}\right.$, calcd. for $\mathrm{C}_{26} \mathrm{H}_{29} \mathrm{O}_{9}, m / z$ 485.1806), implying 13 indices of hydrogen deficiency. The ${ }^{1} \mathrm{H}$ NMR spectrum of 1 showed resonances for four tertiary methyl groups at $\delta_{\mathrm{H}} 0.85(\mathrm{~s}, \mathrm{H}-30), 1.10$ (s, H-28), 1.36 (s, H-18), and 1.43 (s, H-29). Characteristic signals of a $\beta$-substituted furan moiety were observed at $\delta_{\mathrm{H}} 6.52(\mathrm{br} \mathrm{d}, 1 \mathrm{H}$, $J=1.4 \mathrm{~Hz}, \mathrm{H}-22), 7.68(\mathrm{t}, 1 \mathrm{H}, J=1.4 \mathrm{~Hz}, \mathrm{H}-23)$ and $7.73(\mathrm{~m}, 1 \mathrm{H}$, $\mathrm{H}-21)$. The presence of two singlets at $\delta_{\mathrm{H}} 4.36(\mathrm{~s}, 1 \mathrm{H}, \mathrm{H}-15)$ and 5.59 ( $\mathrm{s}, 1 \mathrm{H}, \mathrm{H}-17)$ are in accordance with the presence of the D-ring with a 14,15-epoxy group, typical for limonoids from $D$. vandellianum. ${ }^{2,3}$ Furthermore, signals at $\delta_{\mathrm{H}} 4.17(\mathrm{dd}, 1 \mathrm{H}, J=11.9,2.0 \mathrm{~Hz}, \mathrm{H}-19 \beta), 4.59$ (d, $1 \mathrm{H}, J=11.9 \mathrm{~Hz}, \mathrm{H}-19 \alpha), 5.99$ (d, $1 \mathrm{H}, J=10.0 \mathrm{~Hz}, \mathrm{H}-2)$, and 6.93 (dd, $1 \mathrm{H}, J=10.0,2.0 \mathrm{~Hz}, \mathrm{H}-1$ ) were attributed to A-ring seco limonoid with an $\alpha, \beta$-unsaturated lactone. The chemical shifts of the protons at $\delta_{\mathrm{H}} 4.68(\mathrm{~d}, 1 \mathrm{H}, J=5.0 \mathrm{~Hz}, \mathrm{H}-7)$ and $5.63(\mathrm{~d}, 1 \mathrm{H}, J=5.0 \mathrm{~Hz}, \mathrm{OH}-7)$ were attributed by comparison with literature data. ${ }^{19,20}$ The existence 
Table 1. NMR spectroscopic data of $\mathbf{1}$ and $\mathbf{1 a}(\mathrm{J}$ in $\mathrm{Hz})$

\begin{tabular}{|c|c|c|c|c|c|c|}
\hline \multirow{2}{*}{ position } & \multicolumn{2}{|c|}{$1\left(\mathrm{DMSO}-d_{6}\right)^{\mathrm{a}}$} & \multicolumn{2}{|c|}{$1\left(\operatorname{Pyr}-d_{5}\right)^{\mathrm{b}}$} & \multicolumn{2}{|c|}{$1 \mathbf{a}\left(\operatorname{Pyr}-d_{5}\right)^{\mathrm{b}}$} \\
\hline & $\delta_{\mathrm{H}}$ & $\delta_{\mathrm{C}}$ & $\delta_{\mathrm{H}}$ & $\delta_{\mathrm{C}}$ & $\delta_{\mathrm{H}}$ & $\delta_{\mathrm{C}}$ \\
\hline 1 & $6.93 \mathrm{dd}(10.0,2.0)$ & 149.1 & $6.96 \mathrm{~d}(9.6)$ & 149.0 & 6.99 br d (9.6) & 148.6 \\
\hline 2 & $5.99 \mathrm{~d}(10.0)$ & 121.2 & $6.36 \mathrm{~d}(9.6)$ & 123.1 & $6.36 \mathrm{~d}(9.6)$ & 123.5 \\
\hline 3 & & 161.7 & & 162.5 & & 162.5 \\
\hline 4 & & 61.8 & & 62.7 & & 64.1 \\
\hline 5 & & 73.3 & & 74.7 & & 74.8 \\
\hline 6 & & 205.4 & & 206.2 & & 199.7 \\
\hline 7 & $4.68 \mathrm{~d}(5.0)$ & 81.0 & $5.08 \mathrm{~s}$ & 83.6 & $5.99 \mathrm{~s}$ & 83.2 \\
\hline 8 & & 45.5 & & 47.3 & & 45.5 \\
\hline 9 & $3.05 \mathrm{t}(9.4)$ & 41.0 & $3.36 \mathrm{t}(8.8)$ & 43.2 & $3.43 \mathrm{t}(8.8)$ & 43.7 \\
\hline 10 & & 44.9 & & 46.4 & & 46.3 \\
\hline 11 & $1.80 \mathrm{~m}$ & 17.1 & $1.95 \mathrm{~m}$ & 18.7 & $2.01 \mathrm{~m}$ & 19.0 \\
\hline 12 & $1.67 \mathrm{~m}$ & 25.8 & $1.83 \mathrm{~m}$ & 27.3 & $1.90 \mathrm{~m}$ & 28.0 \\
\hline 12 & $1.32 \mathrm{~m}$ & & $1.53 \mathrm{~m}$ & & $1.53 \mathrm{~m}$ & \\
\hline 13 & & 38.5 & & 39.8 & & 39.9 \\
\hline 14 & & 72.1 & & 72.7 & & 71.6 \\
\hline 15 & $4.36 \mathrm{~s}$ & 55.9 & $5.24 \mathrm{~s}$ & 56.8 & $4.30 \mathrm{~s}$ & 56.5 \\
\hline 16 & & 167.4 & & 168.2 & & 168.2 \\
\hline 17 & $5.59 \mathrm{~s}$ & 77.5 & $5.88 \mathrm{~s}$ & 78.6 & $5.86 \mathrm{~s}$ & 78.6 \\
\hline 18 & $1.36 \mathrm{~s}$ & 18.5 & $1.51 \mathrm{~s}$ & 18.7 & $1.48 \mathrm{~s}$ & 19.0 \\
\hline 19 & $4.59 \mathrm{~d}(11.9)$ & 69.4 & $4.81 \mathrm{~d}(12.0)$ & 70.6 & $4.82 \mathrm{brd}(12.0)$ & 70.5 \\
\hline 19 & $4.17 \mathrm{dd}(11.9,2.0)$ & & $4.72 \mathrm{~d}(12.0)$ & & $4.75 \mathrm{~d}(12.0)$ & \\
\hline 20 & & 120.3 & & 121.5 & & 121.3 \\
\hline 21 & $7.73 \mathrm{~m}$ & 142.0 & $7.74 \mathrm{~s}$ & 142.4 & $7.74 \mathrm{~s}$ & 142.5 \\
\hline 22 & 6.52 br d (1.4) & 110.3 & $6.54 \mathrm{~s}$ & 110.9 & $6.53 \mathrm{~s}$ & 110.9 \\
\hline 23 & $7.68 \mathrm{t}(1.4)$ & 143.2 & $7.67 \mathrm{~s}$ & 144.1 & $7.67 \mathrm{~s}$ & 144.2 \\
\hline 28 & $1.10 \mathrm{~s}$ & 22.0 & $1.10 \mathrm{~s}$ & 22.0 & $1.31 \mathrm{~s}$ & 22.9 \\
\hline 29 & $1.43 \mathrm{~s}$ & 20.9 & $1.53 \mathrm{~s}$ & 21.7 & $1.54 \mathrm{~s}$ & 22.1 \\
\hline 30 & $0.85 \mathrm{~s}$ & 14.4 & $1.23 \mathrm{~s}$ & 15.1 & $1.25 \mathrm{~s}$ & 15.6 \\
\hline $\mathrm{OH}-7$ & $5.63 \mathrm{~d}(5.0)$ & & & & & \\
\hline \multirow[t]{2}{*}{ Ac-7 } & & & & & $2.21 \mathrm{~s}$ & 20.8 \\
\hline & & & & & & 170.3 \\
\hline
\end{tabular}

${ }^{a} 500$ and $125 \mathrm{MHz} .{ }^{\mathrm{b}} 400$ and $100 \mathrm{MHz}$.

of hydroxyl proton signal indicates that no chemical exchange with water molecules, which appears as a DMSO- $d_{6}$ impurity, has occurred. This can be explained by the occurrence of intramolecular hydrogen bonding involving the hydroxyl and carbonyl group.

In the ${ }^{13} \mathrm{C} \mathrm{NMR}$ spectrum of compound $\mathbf{1}$ were observed 26 signals. The chemical shifts at $\delta_{\mathrm{C}} 110.3,120.3,142.0$, and 143.2 were assigned to carbons C-22, C-20, C-21, and C-23, respectively, of the $\beta$-substituted furan moiety. The presence of the 14,15-epoxy $D$-lactone was confirmed by the signals observed at $\delta_{\mathrm{C}} 55.9(\mathrm{C}-15)$, $72.1(\mathrm{C}-14), 77.5(\mathrm{C}-17)$, and $167.4(\mathrm{C}-16)$. The signals at $\delta_{\mathrm{C}} 81.0$ and 205.4 were in agreement with a hydroxyl at C-7 and carbonyl group at C-6. The chemical shifts at $\delta_{\mathrm{C}} 69.4,121.2,149.1$, and 161.7, were attributed to carbons C-19, C-2, C-1, and C-3, respectively, from the A-ring seco limonoid with an $\alpha, \beta$-unsaturated lactone. The presence of two non-hydrogenated carbons at $\delta_{\mathrm{C}} 61.8$ and 73.3 revealed the presence of an epoxy group and were assigned to C-4 and C-5. Methyl groups were observed at $\delta_{\mathrm{C}} 14.4,18.5,20.9$, and 22.0, corresponding to C-30, C-18, C-29, and C-28, respectively.

In its HMBC spectrum, $\mathrm{H}-17\left(\delta_{\mathrm{H}} 5.59\right)$ was correlated to $\mathrm{C}-18$ $\left(\delta_{\mathrm{C}} 18.5\right)$ and $\mathrm{C}-14\left(\delta_{\mathrm{C}} 72.1\right) ; \mathrm{H}-12\left(\delta_{\mathrm{H}} 1.72\right)$ was correlated to $\mathrm{C}-14$ $\left(\delta_{\mathrm{C}} 72.1\right)$ and $\mathrm{C}-17\left(\delta_{\mathrm{C}} 77.5\right)$ thus confirming $1.72 / 25.8$ for $\mathrm{H}-12 / \mathrm{C}-12$. The insertion of a hydroxyl group at C-7 was established by the correlations from H-7 $\left(\delta_{\mathrm{H}} 4.68\right)$ to the carbons Me-30 $\left(\delta_{\mathrm{C}} 14.4\right)$ and C-5 $\left(\delta_{\mathrm{C}} 73.3\right)$, and from $\mathrm{OH}-7\left(\delta_{\mathrm{H}} 5.63\right)$ to $\mathrm{C}-8\left(\delta_{\mathrm{C}} 45.5\right)$ and $\mathrm{C}-6$ $\left(\delta_{\mathrm{C}} 205.4\right)$. The presence of a 4,5 -epoxy group was confirmed by the correlation between $\mathrm{H}-28\left(\delta_{\mathrm{H}} 1.10\right)$ and the carbons C-4 $\left(\delta_{\mathrm{C}} 61.8\right)$ and $\mathrm{C}-5\left(\delta_{\mathrm{C}} 73.3\right)$. H-28 was also correlated to C-29 $\left(\delta_{\mathrm{C}} 20.9\right)$, and $\mathrm{H}-29\left(\delta_{\mathrm{H}} 1.43\right)$ to $\mathrm{C}-28\left(\delta_{\mathrm{C}} 22.0\right)$, corroborating the presence of two methyl groups linked to $\mathrm{C}-4$.

The presence of the lactone ring was verified by the correlations observed between $\mathrm{H}-19\left(\delta_{\mathrm{H}} 4.17\right)$ and carbons C-3 $\left(\delta_{\mathrm{C}} 161.7\right)$ and $\mathrm{C}-5\left(\delta_{\mathrm{C}} 73.3\right)$. Another important correlation was found between $\mathrm{H}-2$ 
$\left(\delta_{\mathrm{H}} 5.99\right)$ and $\mathrm{C}-10\left(\delta_{\mathrm{C}} 44.9\right)$, consistent with a A-ring seco limonoid (Figure 2).

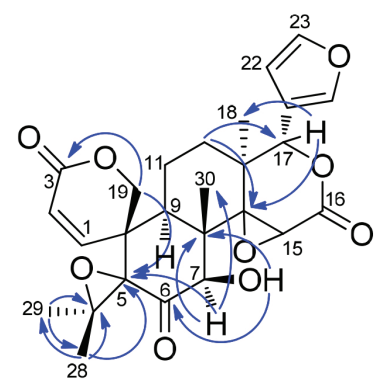

Figure 2. Key HMBC correlations of compound 1

The relative configurations of $\mathbf{1}$ was established by the analysis of the NOESY spectrum (Figure 3). The correlations of Me-18/H-15 suggested the $\beta$-orientation of the 14,15-epoxy group. The correlation of $\mathrm{H}-15 / \mathrm{H}-7$, along with the correlation of $\mathrm{OH}-7 / \mathrm{Me}-30$ revealed the $7 \beta$-equatorial position of the hydroxyl group. The correlations of $\mathrm{H}-7 / \mathrm{H}-9, \mathrm{H}-9 / \mathrm{H}-1$ and $\mathrm{H}-1 / \mathrm{Me}-29$ led to the assignment of the $\alpha$-orientation for these protons. In order to determine the C-15 and C-7 configuration, the acetylation of $\mathbf{1}$ was carried out $\left(\mathrm{Ac}_{2} \mathrm{O} / \mathrm{pyr}\right)$, which gave the $O$-acetyl derivative 1a. Comparison of the ${ }^{1} \mathrm{H}$ NMR spectra of 1 and 1a obtained in pyridine- $d_{5}$ (Table 1) showed a shielding of H-15 of 1a, which suggests that H-15 has a cis relationship with H-7. ${ }^{9}$

Thus, after analysis of the spectra, it was possible to establish that compound $\mathbf{1}$ is a new natural compound with an A-seco-limonoid structure, named dictyolomol.

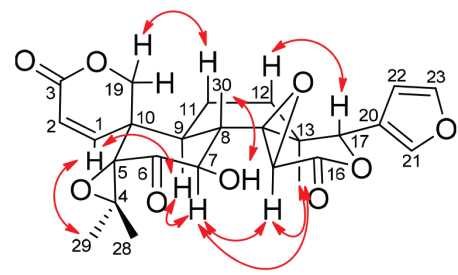

Figure 3. Key NOESY correlations of compound 1

Compounds 1, 1a and $\mathbf{2}$ were evaluated for their cytotoxicities toward two human cancer cell lines (MCF-7 and HeLa). However, the compounds did not demonstrate cytotoxicity against either of these cell lines.

\section{CONCLUSIONS}

The phytochemical study of $D$. vandellianum led to the isolation of a new A-seco-limonoid, dictyolomol (1), and the known alkaloid, casimiroine (2), which was already reported from this species. The cytotoxicity evaluation against MCF-7 and HeLa of these compounds and the corresponding acetyl derivative 1a was investigated. The results were negative for all compounds.

\section{EXPERIMENTAL}

\section{General experimental procedures}

IR were recorded on a BOMEM-MB 100 spectrophotometer. 1Dand 2D-NMR experiments were performed using a Bruker Avance III HD (400 and $100 \mathrm{MHz}$ for ${ }^{1} \mathrm{H}$ and ${ }^{13} \mathrm{C}$, respectively) and Varian NMR (500 and $125 \mathrm{MHz}$ for ${ }^{1} \mathrm{H}$ and ${ }^{13} \mathrm{C}$, respectively) spectrometer. The residual peaks of the deuterated solvents were taken as reference points. High-resolution mass spectrometry (HRMS) analyses were performed on a microTOFII ESI-TOF mass spectrometer. Isolation, purification, and analysis of the chemical constituents were performed using chromatographic methods, including column chromatography (CC), thin-layer chromatography (TLC) and high-performance liquid chromatography (HPLC). A preparative $\mathrm{RP} \mathrm{C}_{18}$ column (ACE; $250 \mathrm{~mm} \times 21.2 \mathrm{~mm} \times 5 \mu \mathrm{m}$ ) was used for the separation. Silica gel (Silicycle ${ }^{\circledR}$, particle size $0.040-0.063 \mathrm{~mm}$ ) was used in CC. Commercial silica gel plates (Whatman) were used in TLC, with a 0.25 -mm-thick layer on an aluminum support $(20 \times 20 \mathrm{~cm})$. The substances were analyzed by using ultraviolet radiation at wavelengths of 254 and $366 \mathrm{~nm}$ (Boitton brand apparatus) and by impregnating the plates in glass chambers saturated with iodine vapor.

\section{Plant material}

The specimens were collected in Morro do Chapéu, Bahia, Brazil

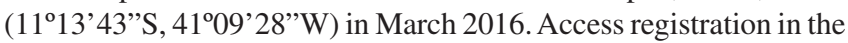
National Management System of Genetic Patrimony and Associated Traditional Knowledge (SISGEN) was obtained under No. A1F8819. The vouchers specimens were identified by Prof. Maria Lenise Silva Guedes and deposited at the Herbarium Alexandre Leal Costa (ALCB), Institute of Biology, Federal University of Bahia with the registration number 123484 .

\section{Extraction and isolation}

Inflorescences of $D$. vandellianum $(706.1 \mathrm{~g})$ were macerated three times in chloroform for seven days. After evaporation of the solvent under reduced pressure the crude extract $(3.5 \mathrm{~g})$ was fractionated by silica gel (70 g) column chromatography (petroleum ether, $100 \%, 5$ fractions; chloroform, 100\%, 17 fractions; $\mathrm{CHCl}_{3}: \mathrm{MeOH}$, 98:2, 4 fractions; $\mathrm{CHCl}_{3}: \mathrm{MeOH}, 95: 5,4$ fractions; $\mathrm{MeOH}, 100 \%$, 3 fractions). 33 fractions of $200 \mathrm{~mL}$ were collected and pooled in 17 groups according to their chromatographic profile on TLC. The fraction group 13-14 (400 mg), obtained after regrouping and drying, was suspended in chloroform and the precipitate separated to obtain the compound $\mathbf{1}(140 \mathrm{mg})$. The fraction 10 was purified by preparative liquid chromatography with $\mathrm{MeCN}-\mathrm{H}_{2} \mathrm{O}(30: 70$, v/v) to obtain $2(3.28 \mathrm{mg})$.

Dictyolomol (1): White powder; $[\alpha]^{25}{ }_{\mathrm{D}}+116$ (c. 0.1, MeCN); IR $(\mathrm{KBr}) \mathrm{v}_{\max } 3430,1738,1700$, and $1058 \mathrm{~cm}^{-1} ;{ }^{1} \mathrm{H}$ and ${ }^{13} \mathrm{C}$ NMR data (500 MHz and $125 \mathrm{MHz}$, respectively, in DMSO- $d_{6}$ ), see Table 1; HRESIMS 485.1807 [M + H] $]^{+}$(calcd. for $\mathrm{C}_{26} \mathrm{H}_{29} \mathrm{O}_{9}, \mathrm{~m} / z$ 485.1806).

\section{Acetylation of dictyolomol (1)}

Acetylation was carried out by dissolving the compound $\mathbf{1}(8 \mathrm{mg})$ in pyridine and $\mathrm{Ac}_{2} \mathrm{O}(1: 2)$ at room temperature. After $24 \mathrm{~h}$, the reaction mixture was carefully added into cold water and extracted successively with $\mathrm{CHCl}_{3}$. The organic layer was washed with aqueous $\mathrm{HCl}$ solution (5\%, v/v), to eliminate pyridine, and with $\mathrm{H}_{2} \mathrm{O}$. Then, the $\mathrm{CHCl}_{3}$ phase was evaporated to dryness using a rotatory evaporator to obtain $\mathbf{1 a}(4.49 \mathrm{mg})$.

\section{Cytotoxicity assays}

MCF-7 (human breast carcinoma cell line) was cultured in RPMI 1640 medium, and HeLa (human epithelioid cervix carcinoma cell line) was cultured in DMEM medium, both culture medium were supplemented with $10 \%$ fetal bovine serum (SBF), $100 \mathrm{U} \mathrm{mL}^{-1}$ penicillin, and $100 \mu \mathrm{g} \mathrm{mL} \mathrm{m}^{-1}$ streptomycin at $37^{\circ} \mathrm{C}$ in a humidified atmosphere with $5 \% \mathrm{CO}_{2}$. Cells were seeded into 96-well plates at a density of $3 \times 105$ cell well $^{-1}$. Following a $24 \mathrm{~h}$ period, cells were 
incubated with the compounds $(25 \mu \mathrm{M})$ dissolved in DMSO $(0.4 \%)$. After culturing for $72 \mathrm{~h}$, the supernatant was discarded, and the 3-(4,5-dimethylthiazol-2-yl)-2,5-diphenyltetrazolium bromide (MTT) solution $\left(5 \mathrm{mg} \mathrm{mL}^{-1}\right)$ was added and incubated for another $3 \mathrm{~h}$. The deposited formazan was dissolved with sodium dodecyl sulfate (SDS) $(100 \mu \mathrm{L}) .{ }^{21}$ Positive control was DMSO (20\%). The optical densities were measured using a microplate reader (Synergy HT, BioTek ${ }^{\circledR}$ ). Data were analyzed with GraphPad Prism 5.0.

\section{SUPPLEMENTARY MATERIAL}

NMR spectra for compounds $\mathbf{1}$ and $\mathbf{1 a}$ can be found at http://quimicanova.sbq.org.br in PDF format, with free access.

\section{ACKNOWLEDGEMENTS}

The authors acknowledge the Brazilian agencies Coordenação de Aperfeiçoamento de Pessoal de Nível Superior-Brasil (CAPES) (Finance Code 001) and Conselho Nacional de Desenvolvimento Científico e Tecnológico $(\mathrm{CNPq})$, for financial support and fellowships. We are also thankful for collaborating with Rede Norte-Nordeste de Fitoterápicos (INCT-RENNOFITO), and the LMCA-Central Analytical from Federal University of Paraíba for obtaining the spectra.

\section{REFERENCES}

1. Macbride, J. F.; Flora of Peru, vol. 13; Field Museum of Natural History: Chigago, 1949.

2. Alves, I. M.; Abreu, L. S.; Costa, C. O. S.; Le Hyaric, M.; Guedes, M. L. S.; Soares, M. B. P.; Bezerra, D. P.; Velozo, E. S.; Chem. Biodiversity 2017, 14, e1600276.

3. Vieira, P. C.; Lázaro, A. R.; Fernandes, J. B.; da Silva, M. F. G. F.; Quim. Nova 1990, 13, 287.
4. Sartor, C. F. P.; da Silva, M. F. G. F.; Fernandes, J. B.; Vieira, P. C.; Fo, E. R.; Cortez, D. A. G.; Phytochemistry 2003, 63, 185.

5. Campos, A. M.; Khac, D. D.; Fetizon, M.; Phytochemistry 1987, 26 , 2819.

6. Roy, A.; Saraf, S.; Biol. Pharm. Bull. 2006, 29, 191.

7. Wijeratne, E. M. K.; Bandara, B. M. R.; Ginatilaka, A. A. L.; J. Nat. Prod. 1992, 55, 1261.

8. Sartor, C. F. P.; Lima, M. P.; da Silva, M. F. G. F.; Fernandes, J. B.; Forim, M. R.; Pirani, J. R.; J. Braz. Chem. Soc. 2019, 30, 2464.

9. Vieira, P. C.; Lázaro, A. R.; Fernandes, J. B.; da Silva, M. F. G. F.; Biochem. Syst. Ecol. 1988, 16, 541.

10. Abreu, L. S.; Alves, I. M.; do Espírito-Santo, R. F.; do Nascimento, Y. M.; Dantas, C. A. G.; dos Santos, G. G. L.; Le Hyaric, M.; Guedes, M. L. S.; da Silva, M. S.; Villarreal, C. F.; Velozo, E. S.; Tavares, J. F.; PLoS One 2019, 14, e0224575.

11. Patridge, E.; Gareiss, P.; Kinch, M. S.; Hoyer, D.; Drug Discovery Today 2016, 21, 204.

12. Thomford, N. E.; Senthebane, D. A.; Rowe, A.; Munro, D.; Seele, P.; Maroyi, A.; Dzobo, K.; Int. J. Mol. Sci. 2018, 19, ID 1578.

13. Newman, D. J.; Cragg, G. M.; J. Nat. Prod. 2016, 79, 629.

14. Zhang, J.; Li, W.; Dai, Y.; Shen, L.; Wu, J.; Mar. Drugs 2018, 16, ID 38.

15. Ma, C.; Liu, X.; Shan, Y.; Xu, S.; Su, X.-1.; Feng, X.; Wang, Q.-Z. Nat. Prod. Commun. 2018, 13, 339.

16. Shang, X. F.; Morris-Natschke, S. L.; Yang, G. Z.; Liu, Y. Q.; Guo, X.; Xu, X. S.; Goto, M.; Li, J. C.; Zhang, J. Y.; Lee, K. H.; Med. Res. Rev. 2018, 38, 1614.

17. Lou, L. L.; Cheng, Z. Y.; Guo, R.; Yao, G. D.; Song, S. J.; Nat. Prod. Res. 2019, 33, 911.

18. Zhang, Y.; Xu, H.; RSC Adv. 2017, 7, 35191.

19. Barrera, C. A. C.; Barrera, E. D. C.; Falla, D. S. G.; Murcia, G. D.; Suarez, L. E. C.; Chem. Pharm. Bull. 2011, 59, 855.

20. Severino, V. G. P.; de Freitas, S. D. L.; Braga, P. A. C.; Forim, M. R.; da Silva, M. F. G. F.; Fernandes, J. B.; Vieira, P. C.; Venâncio, T.; Molecules 2014, 19, 12031.

21. Mosmann, T.; J. Immunol. Methods 1983, 65, 55. 